\title{
Designing the Model of Professional Development of Teachers Taking into Account Axiological Imperatives of Continuing Education
}

\author{
Irina A. Greshilova*, Sesegma Z. Kimova, Balzhit B. Dambaeva \\ Institute of Education Development of Trans-Baikal Territory, Russia \\ Received November 5, 2019; Revised January 27, 2020; Accepted February 18, 2020
}

Copyright $\odot 2020$ by authors, all rights reserved. Authors agree that this article remains permanently open access under the terms of the Creative Commons Attribution License 4.0 International License

\begin{abstract}
The need for continuous personal and professional development is explained in essence by the continuous education of teachers. The purpose of the study is to define the content of a model for the professional development of teachers, taking into account the axiological imperatives of continuing education. The article describes the axiological imperatives of "a person is a subject of continuous education", "a person is a subject of cultural space of continuous education", "a person is a self-developing personality", "continuous education is a semantic activity", and "strategy of own development in the changing world". The content of the model is presented on the basis of the contextual approach and foundation positions. As a result, the axiological, pedagogical and organizational components of the model are described and correlated with the axiological imperatives of continuous education. These components have determined the development of actual forms of professional teacher development. These include scenario development, expert panels and a roadmap. Axiological imperatives of continuous education should be taken into account in the design of any model for the professional development of teachers in international practice to ensure the successful implementation of the developed model.
\end{abstract}

Keywords Personal and Professional Development, Continuous Education of Teachers, Modeling of Professional Development, Axiological Imperatives, Forms of Professional Development

\section{Introduction}

The professional activity of teachers working in preschools, primary schools, basic general education, and secondary general education assumes constant personal and professional development to meet the requirements of the post-industrial information society. Regarding the basic approaches of development, A. McElearney, C. Murphy and D. Radcliffe refer to collaboration and interactivity, which, by contributing to the improvement of pedagogical activities, can improve the personal achievements of students (McElearney, Murphy, Radcliffe, 2019 , p. 433). These approaches relate to the need to develop the professional skills of educators to design and implement the educational process, as highlighted by S. Kim, M. Raza and E. Seidman, namely feedback, reflective action and continuous improvement (2019, p. 99). A high level of development of these skills enables teachers to successfully carry out their work in accordance with their professional activities, e.g., general pedagogical function (training), educational activities and developing activities.

The support from high-level professional skills development accompanies teachers throughout their professional activities, which are built into the context of lifelong learning. Continuing education is also interpreted as "lifelong learning" in international documents certifying formal adult education (Coelli, Tabasso, 2019, p. 205). The reference to lifelong learning is dictated by the peculiarities of the current stage of the development of society in its relationship to education. For a person of the 21 st century living in a globalized, post-industrial information society, only continuing education will ensure that their personal needs are met, both in the workplace and in employment opportunities (Coelli, Tabasso, 2019, p. 206). A. Y. S. Goh emphasizes the meaning of continuous human education, which consists of collective reflexive activity for personal and professional development and the development of the educational organization in which the individual works (Goh, 2019, p. 1). This meaning implies that the purposeful development of a person is a subject of activity throughout their life and 
acts as a means of human self-realization.

The problem of the relevance of education in a dynamically changing world leads to an understanding of the need to identify new priorities for continuing education. In their own context, a person masters reality, shows activity aimed at its transformation, and uses available resources, which must constantly be replenished. The value priorities of lifelong education are based on the demands of society, which reflect the transition from an industrial to a post-industrial information society that nevertheless contains pedagogical conservatism, an insufficient material and technical base, and a regional information and technological imbalance (Lafisheva, Kudayeva, Taisaev, 2017, p. 668).

In the context of continuing education, additional professional programs are offered for the personal and professional development of teachers. These include continuing education (short-term training) and vocational retraining (long-term training). Wide access to continuing education courses is associated with short-term training, which allows teachers to improve their professional skills or improve their professional level within their qualifications. The systematic development of these skills is determined by the growth of the growing use of technology in the basic industries, the free flow of information, and the digitalization of society. The need to design models in the context of continuing education contributes to the increase of professional mobility of and competitiveness among teachers in various fields of activity. It is important to integrate precisely those teachers who have professional experience and practical work skills into the labor market (Rybakina, 2018, p. 32).

The design of an advanced training model is associated with the study of complex systems (scientific worldview, scientific knowledge system, pedagogical systems, learning process) which are characterized by their multidimensionality, inextricable interconnectedness of elements, and a state of uncertainty arising at some stages of their development. The disclosure of the patterns of development of these systems can be facilitated by the use of a cognitive model, which, offering a holistic view of the content of advanced training, simultaneously forms patterns in its components.

Taking into account the value priorities of continuing education in a model of the advanced training of teachers is a mandatory component of its design amongst modern realities. Internal moral attitudes act as a source for the purpose and meaning of "education through life" and are interpreted as axiological imperatives of continuing education. These imperatives determine a comprehensive understanding and transformation of the idea of the internal self-development of the individual as well as a consideration of the problems of the meaningful life of the individual.

The axiological imperatives of lifelong education permeate the entire content of the continuing education model, which means that they must be taken into account when designing its forms to meet the needs of personal self-development and, accordingly, the personal and professional development of teachers. The relevance of the implementation of axiological imperatives in the course of the personal and professional development of teachers is reflected in the purpose of the study, namely to determine the content of the teacher development model taking into account the axiological imperatives of continuing education. When conducting the study, the authors proceed from the following assumption, which determines the hypothesis of the study: The identification of the axiological imperatives of the continuing education of teachers and the determination of the content of models for improving their qualifications will determine the actual forms of the continuing education of teachers.

\section{Literature Review}

The rapid growth of scientific information and its rapid aging as well as the changing requirements for the qualifications of specialists in various fields of knowledge in accordance with the needs of society indicate that a person can no longer gain knowledge for life. This circumstance "suggests the need to complete the educational ladder with new steps designed for all periods of a person's life" (Perezhovskaya, 2015, p. 38). A continuity of education involves not only the assimilation of knowledge by a person and the acquisition of the appropriate abilities, skills and methods of activity but also the formation of their worldview, cognitive interests, abilities and value orientations. The latter include "personal, professional, pedagogical, and socio-cultural values that show the richness of axiological culture" of teachers (Astashova, Bondyreva, Smantser, 2018, p. 52).

Continuing education becomes a sense-forming activity subject to a conscious choice and the free implementation of educational intentions, which contributes to a change in the value orientations of the individual. By reflecting, a person is able to determine the strategy of their own existence in a rapidly changing world, realizing the importance of their influence on the surrounding reality. The value orientations of the personality, suggesting a thirst for learning new things and reflective activity, describe the importance of continuing education for the professional activities of educators (Heijden van der, Geldens, Beijaard, Popeijus, 2015, p. 681).

The Swedish researcher B. Malm notes that it is important to consider the cognitive, social, and emotional components of personal and professional development, which involve coping with conflict, self-understanding, empathy, leadership skills, and collaboration skills (Malm, 2009, p. 77). Italian researchers have also addressed this issue, which points to the critical understanding and adaptation by teachers of techniques, methods, and educational resources for the implementation of educational innovations, which implies the implementation of online or blended learning (Limone, 
Pace, 2018, p. 657). In addition, researchers from Spain have focused on full-time, blended or online learning in the continuing education of educators (Breddermann, Martínez-Cerdá, Torrent-Sellens, 2018, p. 399).

During decision-making, teachers as subjects of the cultural space of lifelong education not only learn the existing cultural patterns but also engage in cultural contexts that encourage them to deepen their cultural experience (Smolcic, Katunich, 2017, p. 47). This process is expressed in the possibility of reading cultural texts, thus acquiring the ability to create new ones. The creation of new cultural texts in the post-industrial information society is associated with the ability to use information and communication technologies in professional activities (Cendon, 2018, p. 81). Effective decision-making, deepening cultural experience and the ability to use information and communication technologies are impossible without the internal moral attitudes of teachers. Serving as the purpose and meaning in the context of continuing education, they become imperatives or moral precepts. It is axiological imperatives, that is, the internal moral principles, of the continuing education of teachers that determine their personal and professional development.

Internal moral attitudes are determined by the idea of entering the cultural space of lifelong education (Mokshina, 2015), where a person comprehends themselves in the culture and assimilates cultural values, the transfer of which to the internal plane consciously leads to the mastery of systemic thinking. Guided by the fact that axiological imperatives act as a source of the purpose and meaning of lifelong education, they consider a person a subject of lifelong education since the internal impulse to action implies a successful organizing of the start of self-determination. In this regard, axiological imperatives contribute to the appropriation of cultural methods of the cognition of reality as new qualities.

Axiological imperatives are the following internal installations. First, a person manifests himself or herself in the substantiation of their essence only under the condition of freedom of choice. This is how they realize themselves in the world and build an attitude towards themselves in relation to themselves, acquiring a certain freedom in setting the goals to be achieved (Bakken, 2019, p. 105). Teachers' freedom of choice in setting the personal and professional goals of continuing education in the context of lifelong education determines such axiological imperatives as "a person is a subject of continuing education" and "a person is a subject of the cultural space of lifelong education".

Secondly, the analysis by E. I. Sokolova of the features of continuing education in European countries that are leaders in this field (Denmark, Finland, France, Sweden, the Netherlands) shows people's satisfaction with the standard of living. In this regard, they have a high possibility for competitiveness (Sokolova, 2017). In each region of any country, a different socio-economic situation develops in conjunction with which professional skills determining the ability to compete in the labor market become popular. The ability of teachers to be competitive in the labor market, leading to satisfaction with the standard of living, explains the following axiological imperatives of their continuing education. These include "a person is a self-developing personality" and "lifelong education - meaning-forming activity."

Thirdly, a person has their own value, which gives them the ability to manage circumstances. Constantly improving, a person acquires a tendency to engage in foresight and confidence regarding professional activities. In addition to the confidence of teachers in the implementation of their activities, A. Iredale also refers to skills based on knowledge of the subject area and a creative approach (Iredale, 2018, pp. 163-169). So, the axiological imperative "own development strategy in a changing world" is based on the personal value of teachers' personalities for managing their advanced training.

The investigated axiological imperatives are laid down in the main models of teacher training. One of the existing models is called lifelong learning (LLL), which implies the continuation of the lifelong education of educators in connection with their increasing qualifications (Čepić, Vorkapić, Lončarić, Anđić, Mihić, 2015, p. 8). The next model is presented by "adult education", which refers to the necessity of reintegrating into the adult labor market with a certain professional experience (Beavers, 2009, p. 25). "Continuing vocational education and training" describes the next model; this should promote career development skills (Steeg, Maier, 2019). The fourth model of teacher training is laid down in the "professional standard", which describes the qualifications required to carry out a certain type of professional activity (Miroshnikova, 2015). The "national system of professional growth" introduces the fifth model, which determines the levels of competency and explains the direction of training in a continuing education program to eliminate the identified professional deficits (Malevanov, Kalashnikova, Bolotina, Zharkova, 2017, p. 6).

The content of these models is consistent with the ideas of the continuing education of teachers, but it does not disclose how the axiological imperatives studied here of the continuing education of teachers are implemented therein. It is important to constantly update the content of continuing education in the post-industrial information society, taking into account the internal moral attitudes of teachers. Considering the components of the continuing education model will ensure that the modeling process is successful for implementation in the context of continuing education everywhere in the professional activities of educators. Therefore, it is important to emphasize the studied components of the model, reflecting axiological imperatives and relying on international experience to implement it in different countries. 


\section{Methods}

Designing a model for the advanced training of teachers is presented in the form of a basic complex of interrelated elements. This complex acts as a methodological tool for the study of pedagogical systems and as a substantive-procedural didactic model in constructing the content of the continuing education of teachers. The creation, based on axiological imperatives, of a teacher development model aimed at achieving the required level of professional skills meets the current social requirements.

The theoretical and methodological basis of the study was composed of two approaches, namely the contextual approach and the provisions of the foundation. The contextual approach highlighted by A. A. Verbitsky provides for professional activities based on modeling the language, the iconic means of the subject field and its social content (Verbitsky, 2010). In the process of modeling, professional skills are a means of solving the problems concerning the professional activity of teachers. They help to recreate real professional situations and the fragments of the relations of people employed in them, with the aim of understanding labor functions and actions using a system of new and traditional forms and teaching methods. A. A. Verbitsky refers to them as business and educational games (communication games, protection games against manipulation, games for the development of intuition, reflection games, etc.) (Verbitsky, 2010).

The modeling of professional activity should be considered on the basis of the educational-value model. According to K. D. Kamenova, this model has three main components. The first component is the need for continuing education. On the one hand, it is presented as a continuous and purposeful process of a person mastering professional and other knowledge that allows them to remain creatively active throughout their life. On the other hand, lifelong education is seen as a way of continuously transferring domestic and scientific knowledge. The second component of the model is represented by the subject, that is, a creatively active person directly related to collective activity. The path is defined as the third component of the model; it involves an orientation to approaches that can ensure that the educational paradigm matches a number of the changing determinants of the socio-educational situation (Kamenova, 2010).

The conceptual provisions of the foundation are substantiated by V. D. Shadrikov and E. I. Smirnov (Smirnov, 2012). These provisions indicate that during the training of teachers, the formalization and materialization of cognitive processes take place in the form of specific educational disciplines and forms of educational activity. Cognitive processes form skills that allow them to carry out labor functions. The content of these skills includes motivation, emotions, reflection, self-regulation, self-esteem, choice, intelligence and the creativity of a person.
Fundierung is a process of creating model components to update the professional skills and labor functions of teachers in accordance with the types of professional activities. Fundierung also includes the specification of the content of training, followed by a theoretical generalization of structural units into modules. These modules integrate professional skills and labor functions in the types of professional teacher activities. The fundierung concept of the process of formation of the personality of teachers is an effective mechanism for overcoming professional crises and updating the integrative links between science, professional education, the labor market and the qualification assessment system.

This article reveals the results of the first stage of the study. At this stage, the content of the teacher training model is determined through the analysis and synthesis of the scientific literature. Foreign and domestic sources devoted to five models of the continuing education of teachers are analyzed (see the Literature Review and Analysis section). For the synthesis, the authors compared the selected content of the model with the axiological imperatives of continuing education under study. This comparison allowed the authors to determine the actual forms of teacher training based on the selected components of the model.

These forms are reflected in the implementation of the activities of the Federal Program for the Development of Education for 2016-2020 in the Trans-Baikal Territory as the main region for the current study:

- In direction 2.2. "Improving the quality of education in schools operating in adverse social conditions by implementing regional projects and disseminating their results" in the Trans-Baikal Territory in 2017-2018. The goal of the project is to provide a comprehensive model to manage the processes of improving the quality of education in schools of the Trans-Baikal Territory with low learning outcomes It is supposed to provide continuing education and self-education of teachers in schools operating in adverse social conditions. This should be carried out through managerial, resource, providing conditions and mechanisms aimed at improving the basic indicators of the quality of educational activities.

- In direction 5.1. "Development of a national-regional system of independent quality assessment of general education through the implementation of pilot regional projects and the creation of national quality assessment mechanisms". The goal of this area is the development of a regional system for assessing the quality of education, including technological, information and methodological support for national and regional systems to assess the quality of education; the creation of regional assessment tools for conducting quality assessment procedures for general education as well as advanced training for specialists ensuring the implementation of these measures. 
Table 1. The content of the axiological component of the teacher development model

\begin{tabular}{|c|c|c|c|}
\hline № п/п & $\begin{array}{l}\text { Teacher continuing } \\
\text { Education models }\end{array}$ & $\begin{array}{l}\text { Axiological imperatives of continuing } \\
\text { education of teachers }\end{array}$ & The results of teacher training \\
\hline 1 & Lifelong education & $\begin{array}{l}\text { A person is a subject of continuing } \\
\text { education }\end{array}$ & Additional professional training program \\
\hline 2 & Adult education & $\begin{array}{l}\text { A person is a subject of the cultural space of } \\
\text { continuing education }\end{array}$ & Vocational education program \\
\hline 3 & $\begin{array}{l}\text { Continuing } \\
\text { professional } \\
\text { education }\end{array}$ & A person is a self-developing personality & The content of the additional professional program \\
\hline 4 & Professional standard & $\begin{array}{l}\text { Lifelong education }- \text { meaning-forming } \\
\text { activity }\end{array}$ & $\begin{array}{l}\text { Generalized labor function, labor function, labor } \\
\text { action, skills, knowledge }\end{array}$ \\
\hline 5 & $\begin{array}{l}\text { National } \\
\text { Professional } \\
\text { Development System }\end{array}$ & $\begin{array}{l}\text { Own development strategy in a changing } \\
\text { world }\end{array}$ & $\begin{array}{l}\text { A system based on a level assessment of professional } \\
\text { competencies (subject, methodological, } \\
\text { psychological, pedagogical and communicative) }\end{array}$ \\
\hline
\end{tabular}

\section{Results}

The design of the content of the teacher development model is governed by its main components. The authors pay attention to axiological, pedagogical and organizational components, among others. The choice is based on the need to take into account axiological imperatives and introduce the idea of the internal moral attitudes of teachers into the composition of the studied models.

The content of the axiological component of the model is presented in Table 1, which also reflects the result of teacher training in the context of continuing education.

The pedagogical component of the content of the teacher qualification model includes several basic components, which also reflect all the axiological imperatives studied. The post-industrial information society, which dictates the modernization and restructuring of the educational institution as a whole, gives the basic setting, namely the continuous improvement of teachers. A willingness to act under changing conditions and in the presence of high dynamics in solving professional problems in various types of pedagogical activity is a command of the time, which accordingly requires a change in the nature of knowledge itself. Dynamics are possible taking into account the mandatory use of information and communication technologies in the continuing education system of teachers. These technologies underlying the pedagogical component of the model justify the implementation of lifelong education as a meaning-forming activity in which teachers act as subjects of lifelong education.

Changes in the field of education cannot but affect the social, cultural and historical foundations of education in general. Given the peculiarity of the conditions of the post-industrial information society, the value-semantic content of knowledge acquired by educators throughout life, which contributes to the translation of cultural values, is especially important. The translation of cultural values in this society, which serves as the next component of the pedagogical component of the model, is correlated with an axiological imperative such as "a person is a subject of the cultural space of continuing education".

The study of the problems of lifelong education is based on the fact that personal qualities are needed that would allow teachers to change the world for the better, anticipate the challenges and threats not previously established in educational activities, and also consciously and actively confront them. Modern educators should be creative individuals capable of reorienting moral values and redefining the meaning of their life in a professional manner. The personal potential for the implementation of creative activity, which determines the pedagogical component of the content of the model, characterizes the teacher as a self-developing individuality.

A person in the process of continuing education forms a generalized, justified system of ideas that modern society needs fully educated people who are capable of mobility and cooperation and possess such qualities as constructiveness and responsibility. To ensure the sustainable development of society and the individual, basic traits are needed that contribute to self-development and self-realization. Teachers who are constantly experiencing limitations in their existing professional skills are able to realize that the acquired norms and values are also subject to a constant revaluation from the position of acquired pedagogical experience. The next component of the pedagogical component of the teacher development model is the need for regular reflective activity. According to this, such an axiological imperative as "own development strategy in a changing world" is realized.

The organizational component of the content of the studied model is based on changes in state policy in the field of education, which are enshrined in legislative and regulatory documents. These changes relate to the wording of the essence of education, which focuses on taking into account the interests of the pedagogical community in the course of modeling advanced training for personal and professional development. These interests relate to the need for continuing education and are reflected in the axiological imperatives "a person is a subject of continuing education", "a person is a subject of the cultural space of lifelong education" and "a person is a 
self-developing personality".

Taking the interests of the pedagogical community into account correlates with the concept of qualifications in accordance with a professional standard. The professional standard "teacher of vocational education, vocational education and continuing education" reveals the content of the teacher. The national system of teacher growth makes it possible to streamline the criteria for assessing professionalism, brings them to a common denominator, and allows a teacher of any level to demonstrate their professional skills and experience and build a career path. These ideas correspond to the axiological imperatives "lifelong education - meaning-forming activity" and "own development strategy in a changing world".

The implementation of the axiological imperatives of continuing education in the design of a model for the advanced training of teachers is presented in Table 2.

The axiological, pedagogical and organizational components of the content of the teacher development model determine the vector and content of the development of relevant advanced training forms. These include scenario development, expert panels and a roadmap.

The development of scenarios involves the creation of scenarios for the development of various technological areas, based on an analysis of future opportunities and alternative development paths. A scenario, built taking into account its inclusion in continuous activities to improve their own potential, allows teachers to meet expectations. Purposeful personal attitudes require the advanced training of teachers and preparation for the implementation of the necessary transformations aimed at improving the quality of education - this is an ongoing process of modernizing the content and technologies of education.

The context of continuing education involves dynamic modeling, a kind of immersion of a person in the subject and social content of their profession, and ensures the effectiveness of cognitive activity. Cognitive activity, indeed, is associated with the constant replenishment of existing knowledge from various sources, thereby expanding their range. The knowledge gained is used in a teacher's abilities and desire for innovative activity, which means a continuous search for new knowledge. This desire for innovation and attachment to collective creativity and social progress determines satisfaction with personal and professional development.

In a situation of continuity, an important role is played by modern means of communication, such as webinars, coworking, workshops, hackathons, and BarCamp. A webinar involves conducting professional meetings through a downloadable application (or web application) in real time.

Coworking (co-working) is combined with the flexible organization of the work of different teachers in a common space with the goal of forming a professional community with an internal culture. A small group of teachers gathers for a workshop to exchange professional experience. Educators can be hired for the hackathon to help software developers work on a professional issue in the forum. BarCamp proposes an international conference network created by educators as participants to discuss their professional interests.

Expert panels imply an interaction between representatives of various scientific disciplines and fields of activity, which is difficult to organize under other conditions. The creation of panels is necessary to interpret the results obtained, determining the source information.

An example of expert panels is the Regional Scientific and Expert Council - a permanent advisory body of the Ministry of Education, Science and Youth Policy of the Trans-Baikal Territory, which reviews scientific, analytical and expert support issues for the development of the regional education system and prepares recommendations and proposals. This body brings together a qualified professional community focused on solving prognostic, analytical, evaluative and expert tasks in the interests of developing a regional education system and stimulating the innovative activity of teachers and pedagogical teams and creating a holistic innovative infrastructure for the region's education system.

Table 2. The content of the teacher training model taking into account the axiological imperatives of continuing education

\begin{tabular}{|c|c|c|c|c|}
\hline \multirow{2}{*}{ No. } & \multirow{2}{*}{$\begin{array}{l}\text { Axiological imperatives of } \\
\text { continuing education of teachers }\end{array}$} & \multicolumn{3}{|c|}{ Components of the content of the teacher development model } \\
\hline & & Axiological & Pedagogical & Organizational \\
\hline 1 & $\begin{array}{l}\text { A person is a subject of } \\
\text { continuing education }\end{array}$ & Lifelong education & $\begin{array}{l}\text { The use of information and } \\
\text { communication technologies in the system } \\
\text { of continuing education of teachers }\end{array}$ & \multirow{3}{*}{$\begin{array}{l}\text { Taking into account } \\
\text { the interests of the } \\
\text { pedagogical } \\
\text { community }\end{array}$} \\
\hline 2 & $\begin{array}{l}\text { A person is a subject of the } \\
\text { cultural space of continuing } \\
\text { education }\end{array}$ & Adult education & $\begin{array}{l}\text { Broadcast cultural values in the } \\
\text { information society }\end{array}$ & \\
\hline 3 & $\begin{array}{l}\text { A person is a self-developing } \\
\text { personality }\end{array}$ & $\begin{array}{l}\text { Continuing } \\
\text { professional education }\end{array}$ & Personal potential for creative activity & \\
\hline 4 & $\begin{array}{l}\text { Lifelong education } \\
\text { meaning-forming activity }\end{array}$ & Professional standard & $\begin{array}{l}\text { The use of information and } \\
\text { communication technologies in the system } \\
\text { of continuing education of teachers }\end{array}$ & \multirow{2}{*}{$\begin{array}{lr}\text { Qualification } & \text { in } \\
\text { accordance } & \text { with } \\
\text { professional } & \\
\text { standards } & \end{array}$} \\
\hline 5 & $\begin{array}{l}\text { Own development strategy in a } \\
\text { changing world }\end{array}$ & $\begin{array}{l}\text { National career } \\
\text { development system }\end{array}$ & The need for regular reflective activity & \\
\hline
\end{tabular}


The organization of regional innovative scientific and educational sessions also refers to expert panels. Holding such sessions under the general theme of "Designing innovative activity in education: from concept to implementation" is determined by the general strategies for the innovative development of the socio-economic sphere in Russia in accordance with the law "On Education in the Russian Federation".

The roadmap involves the involvement of experts to develop long-term development strategies for the industry and organization; it illustrates the stages of the transition from the current state to the stages of development. The main advantage of this form of advanced training is the definition of a consistent vision for the long-term development goals of the organization.

Employees of the Institute for the Development of Education of the Trans-Baikal Territory participate in the implementation of large-scale federal and regional educational projects and programs. Organizational, scientific and methodological support was provided for the following areas in the innovative development of the education system of the Trans-Baikal Territory in accordance with the approved action plans (roadmaps):

In the implementation of the project "Improving the information and communication competence of educators in the Trans-Baikal Territory" (2018-2019);

- In the formation and introduction of a national system of teacher growth;

- Improving the linguistic and methodological competencies of foreign languages and preparing students for the state final certification in a foreign language;

- In the implementation of the concept for the development of school information and library centers of the Trans-Baikal Territory for 2018-2025;

- Accompanying the pilot introduction of the federal state educational standard of secondary education in 2017-2020;

- In the organizational, scientific and methodological support of the introduction in the Trans-Baikal Territory of the integrated course program "Trans-Baikal Studies" for 5-9 classes of educational institutions in a pilot mode;

- In the formation and maintenance of a regional training network for the most popular, new and promising professions and specialties of secondary vocational education based on the creation of a regional platform for networking;

- In the introduction of a professional standard at the Institute for the Development of Education of the Trans-Baikal Territory.

Each of the roadmaps is a visual representation of a step-by-step scenario for the development of a certain direction, which is considered an effective way to solve managerial tasks and processes and as a mechanism for setting and solving certain problems. The implemented roadmaps are defined as actionable, that is, they include a number of activities aimed at ensuring the improvement of education in the Trans-Baikal Territory. The purpose of the activity, the main directions, and the expected results are determined in accordance with the roadmaps, the main regulatory documents upon which the mapping is based are listed, and the various quantitative characteristics are presented. The content of each roadmap is devoted to the description of measures to improve the efficiency and quality of services in the field of education, including a list of events, implementation deadlines and expected indicators.

The roadmap links together the vision, strategy and plan for the innovative development of individual areas in the education system of the Trans-Baikal Territory and builds its perspective. Constructing a roadmap involves group work, which means it forms within the group a common understanding of the problem and the possession of a plan for its solution. Each of the roadmaps has specific features and performs certain functions, taking into account the adjustment of individual events.

\section{Discussion}

The content of the teacher training model in the context of continuing education, including the proposed forms of teacher training, is permeated by the implementation of the basic axiological imperatives. These imperatives correspond to the value orientations of the modern education system since values play an important role in the formation of personality. This idea of S. A. Vlasov, which explores the axiological aspect of education, is confirmed by the fact that a qualitative leap in any society becomes possible only when new value orientations mature; each society creates its own specific set of values expressing dominant interests, goals and principles (Vlasov, 2013, p. 53).

The processes of globalization that permeate the post-industrial information society affect the everyday lives of ordinary people. A person integrates the ongoing social processes, with a focus on their values, interests, needs and expectations that is largely dependent on their moral attitudes. Being the subject of their own activity, a person attaches great importance to interaction with surrounding objects, through which they assimilate values in the process of continuing education.

The axiological imperatives of lifelong education under study correspond to the important processes of the post-industrial information society. The dynamic challenges of the 21 st century require the interaction of the individual and society since the intellectual potential should help to overcome the alienation of the technological environment from humans. In the process of this interaction, the newly acquired knowledge should open up additional opportunities for the teacher, increasing their degree of freedom in making professional 
decisions. Personal accessibility to the use of information is largely determined by the processes of appropriation of the methods of professional activity, existing experience, and the development of ways to resolve emerging professional problems. Each teacher treats the situation differently and its transformation, in accordance with its inclinations - including in the life situation - establishes a kind of contact with reality, that is, it manifests its subjectivity. Thus, the importance of subjectivity in the post-industrial information society convinces us of the need to implement the axiological imperative "a person is the subject of lifelong education."

The world is changing, people and attitudes towards the world are changing, and human intellectual development is carried out in powerful information flows, which have their own development trends as independent systems. The main skill of teachers is understanding and the ability to manage the information space because at present it is recognized as one of the conditions for self-affirmation. In the process of continuing education, teachers project subjective representations of cultural content in a subject activity, which are then transferred to all types of professional activity. Culture is the fundamental connection of educators with the world, reflecting their essential subject-object and subject-subject relations. The cultural component of the management of information space indicates the importance of the axiological imperative "a person is the subject of the cultural space of lifelong education."

In the situation of the 21 st century, a person must continue to develop their natural abilities. The intellectual abilities of teachers are a powerful psychological resource that must be used for a self-sufficient and productive life and, only for this, teachers need to be assisted in the development of cognitive interests and the desire to constantly improve their existing potential. The development of the intellectual capabilities of the personality is characterized by such an axiological imperative as "a person is a self-developing individuality".

In lifelong education, there are not only temporary boundaries but also the boundaries of an activity set for oneself, because a person in the process of cognitive activity comprehends its openness and unpredictability. Unpredictability is seen in the fact that the continuing education model in this context guides educators toward the "future", towards constantly changing and opening up new spaces for professional activity, which makes it possible to optimally combine its constant and variable components. The unpredictability of a future-oriented model relates to the following axiological imperative: "lifelong education - meaning-forming activity".

In providing complete freedom in planning one's own learning process throughout life, you can ensure the activation of cognitive activity of a person. The essence of the goal of continuing education allows us to define this phenomenon as a mechanism for preparing for the future. Determining for themselves the landmarks of the future, teachers make an individual ascent to a given goal, building a trajectory of their own educational needs. The design of one's future as a result of the freedom to plan training is related to the strategy of one's own development in a changing world as an axiological imperative.

The axiological imperatives of continuing education should be taken into account when designing any model for the advanced training of teachers in international practice, which is the significance of the study conducted by the authors. Other researchers need to rely on the highlighted internal moral principles in order for the implementation of the developed model to be successful.

The implementation of the axiological imperatives of the teacher advanced training model is correlated with the formation of the teacher's axiosphere, proposed by the Russian researcher N. A. Astashova in the conceptual model of the dialogue space of education. In her opinion, the formation and development of the teacher's axiosphere "will allow building the educational process as a world of culture and a system of creative implementation of joint activities" (Astashova, Bondyreva, Smantser, 2018, p. 62), which is the basis of their personal and professional development.

Among modeling technologies for the advanced training of teachers to meet the requirements of the post-industrial information society, digital technology is worth mentioning (Cendon, 2018). The use of web platforms that offer additional professional programs is relevant and should be taken into account when implementing the model studied by the authors.

Among the relevant forms of teacher training, it is advisable to indicate those who are based on the principles of cooperation and interactivity. Collaborative forms include group work, interactive sessions, coaching, and mentoring, as presented by A. McElearney, C. Murphy, and D. Radcliffe. They also focus on interactive forms such as self-esteem, discussion and debate, and situational task analysis (2019). These forms should be woven into the teachers' continuing education forms already described by the authors, namely scenario development, expert panels and a roadmap.

\section{Conclusions}

At the present stage of the development of society, the implementation of the labor function of teachers in accordance with the types of professional activity is associated with the continuous development of their professional skills. This development is correlated with the self-realization of teachers in the course of professional activity, which is facilitated by additional professional programs for the personal and professional 
development of teachers. Short-term training in these programs, represented by continuing education courses, should be effective for educators themselves in the context of continuing education. In this regard, it is necessary to take into account the value priorities of continuing education in the model of the advanced training of teachers, and therefore also take into account the internal moral principles, or axiological imperatives of continuing education, which determine the personal and professional development of teachers.

These features are reflected in the study conducted by the authors, namely that the content of a teacher development model is determined by taking into account the axiological imperatives of continuing education ("a person is a subject of continuing education", "a person is a subject of the cultural space of continuing education", "a person is a self-developing personality", "lifelong education - meaning-forming activity", and "own development strategy in a changing world"). The content of the teacher training model has three components: axiological, pedagogical and organizational.

When describing the axiological component, such models as lifelong education, adult education, continuing professional education, professional standard, and national system of professional growth are used. The following components are taken into account in the pedagogical component of the teacher's qualification model: the mandatory use of information and communication technologies in the continuing education system of teachers, the translation of cultural values in the information society, the personal potential of creative activity, and the need for regular reflective activity. The organizational component of the model takes into account the interests of the pedagogical community during the modeling of advanced training for personal and professional development as well as qualifications in accordance with the professional standard.

When developing scenarios tailored to be included in a continuous effort to improve one's own potential, an important role is played by modern means of communication, such as webinars, coworking, workshops, hackathons, and BarCamp. Expert panels imply an interaction between representatives of various scientific disciplines and fields of activity, for example, in the Regional Scientific and Expert Council and in the organization of regional innovative scientific and educational sessions. The roadmap includes a number of activities aimed at ensuring the improvement of education.

The distinguished axiological imperatives are consistent with the basic ideas of the post-industrial information society, namely the importance of subjectivity in this society, the cultural component of managing the information space, the development of the intellectual capabilities of a person, the unpredictability of a future-oriented model, and the design of one's future as a result of the freedom of educational planning.
The results should be used in organizing continuing education courses for teachers in international pedagogical practice since in this case the internal moral principles of the continuing education of teachers will be implemented. Also, the disclosure of the axiological imperatives of continuing education and the content of teachers' continuing education models will be appropriate in the course of studying the relevant disciplines in the higher education system, i.e., undergraduate, specialty and magistracy, and graduate school.

In the context of the research undertaken, it is also advisable to investigate and determine design tools, mechanisms and conditions for the implementation of the teachers' continuing education model.

\section{REFERENCES}

[1] Astashova, N.A., Bondyreva, S.K., Smantser, A.P. (2018). Development of the axiosphere of the future teacher in the dialogue space of modern education. Obrazovanie i Nauka [The Education and Science Journal], 20(7), 32-67. doi:10.17853/1994-5639-2018-7-32-67 (in Russian)

[2] Bakken, A.S. (2019). Questions of autonomy in English teachers' discursive practices. Educational Research, 61(1), 105-122. doi: 10.1080/00131881.2018.1561202

[3] Beavers, A. (2009). Teachers as learners: Implications of adult education for professional development. Journal of College Teaching \& Learning (TLC), 6(7), 25-30. doi:10.19030/tlc.v6i7.1122

[4] Breddermann, J., Martínez-Cerdá, J., Torrent-Sellens, J. (2018). A model for teacher training to improve students' 21st century skills in online and blended learning: An approach from film education. In I. Management Association (Ed.), Teacher Training and Professional Development: Concepts, Methodologies, Tools, and Applications (pp. 399-427). Hershey, PA: IGI Global. doi:10.4018/978-1-5225-5631-2.ch018

[5] Cendon, E. (2018). Lifelong learning at universities: Future perspectives for teaching and learning. Journal of New Approaches in Educational Research, 7(2), 81-87. doi: 10.7821/naer.2018.7.320

[6] Čepić, R., Vorkapić, S.T., Lončarić, D., Anđić, D., Mihić, S.S. (2015). Considering transversal competencies, personality and reputation in the context of the teachers' professional development. International Education Studies, 8(2), 8-20. doi:10.5539/ies.v8n2p8

[7] Coelli, M., Tabasso, D. (2019). Where are the returns to lifelong learning? Empirical Economics, 57(1), 205-237. doi:10.1007/s00181-018-1433-8

[8] Goh, A.Y.S. (2019). Rethinking reflective practice in professional lifelong learning using learning metaphors. Studies in Continuing Education, 41(1), 1-16. doi:10.1080/0158037X.2018.1474867

[9] Heijden, H.R.M.A. van der, Geldens, J.J.M., Beijaard, D., Popeijus, H.K. (2015). Characteristics of teachers as 
change agents. Teachers and Teaching, 21(6), 681-699. doi:10.1080/13540602.2015.1044328

[10] Iredale, A. (2018). Teacher Education in Lifelong Learning: Developing Professionalism as a Democratic Endeavour. Leeds, UK: Palgrave Macmillan.

[11] Kamenova, D.K. (2010). Nepreryvnoe obrazovanie kak obrazovatel'no-cennostnaja model' [Continuing education as an educational-value model]. Obrazovaniye cherez vsyu zhizn': nepreryvnoye obrazovaniye $\mathrm{V}$ interesakh ustoychivogo razvitiya [Lifelong Learning: Continuing Education for Sustainable Development], 8, 463-467. (in Russian)

[12] Kim, S., Raza, M., Seidman, E. (2019). Improving 21-st century teaching skills: The key to effective 21-century learners. Research in Comparative and International Education, 14(1), 99-117. doi:10.1177/1745499919829214

[13] Lafisheva, M.M., Kudayeva, F.K., Taisaev, D.M. (2017). Informatization of education in the context of post-industrialization: The difficulties. Proceedings of the 2017 International Conference "Quality Management, Transport and Information Security, Information Technologies", IT and QM and IS 2017, 668-670. doi:10.1109/ITMQIS.2017.8085912 (in Russian)

[14] Limone, P., Pace, R. (2018). Teacher training and digital paths: Revolution in the school - A project for lifelong learning. In I. Management Association (Ed.), Teacher Training and Professional Development: Concepts, Methodologies, Tools, and Applications (pp. 657-675). Hershey, PA: IGI Global. doi:10.4018/978-1-5225-5631-2.ch029

[15] Malevanov, E.Yu., Kalashnikova, N.G., Bolotina, T.V., Zharkova, E.N.(2017). Novye ocenochnye procedury v nacional'noj sisteme uchitel'skogo rosta na osnove ucheta ocenok vypusknikov proshlyh let [New assessment procedures in the national system of teacher growth based on the grades of past graduates]. Innovative projects and programs in education [Innovacionnye proekty i programmy v obrazovanii], 1. 6-17. (in Russian)

[16] Malm, B. (2009). Towards a new professionalism: Enhancing personal and professional development in teacher education. Journal of Education for Teaching, 35(1), 77-91. doi:10.1080/02607470802587160

[17] McElearney, A., Murphy, C., Radcliffe, D. (2019). Identifying teacher needs and preferences in accessing professional learning and support. Professional Development in Education, 45(3), 433-455. doi:10.1080/19415257.2018.1557241

[18] Miroshnikova, O.Kh. (2015). Professional'nyj standart pedagoga: mezhdunarodnyj opyt i regional'nyj komponenty [The teacher's professional standard: international experience and regional components]. Internet-zhurnal "Naukovedenie" [Internet-journal "Science of Science"], 7(3). doi: 10.15862/53PVN315 (in Russian)

[19] Mokshina, N.G. (2015). Pedagogical maintenance of future teachers' practice-oriented training. Indian Journal of Science and Technology, 8(10).doi:10.17485/ijst/2015/v8iS(10)/84853

[20] Perezhovskaya, A.N. (2015). Nepreryvnoe obrazovanie: celi, zadachi, soderzhanie, funkcii, perspektivy razvitija [Continuing education: goals, objectives, content, functions, development prospects. In Problemy i perspektivy razvitija obrazovanija: materialy VI Mezhdunar. nauch. konf. [Problems and prospects for the development of education: materials of the VI Intern. scientific conf.], April 2015, Perm', Russia, pp. 38-41. Perm': Merkurij. Retrieved from: https://moluch.ru/conf/ped/archive/149/7617/ (in Russian)

[21] Reyes-Fournier, E. (2017). Lifelong and lifewide learning. In Distance Learning: Perspectives, Outcomes and Challenges (pp. 1-15). Florida: Nova Science Publishers, Inc.

[22] Rybakina, N.A. (2018). Educational competence: The essence and pedagogical model of formation in the context of lifelong education. Obrazovanie i Nauka [The Education and Science Journal], 20(5), 32-55. doi: 0.17853/1994-5639-2018-5-32-55 (in Russian)

[23] Smirnov, E.I. (2012). Fundirovanie v professional'noj podgotovke i innovacionnoj dejatel'nosti pedagoga: monografija [Funding in the training and innovative activities of a teacher: a monograph]. Yaroslavl: Chancellor Publishing House. (in Russian)

[24] Smolcic, E., Katunich, J. (2017). Teachers crossing borders: A review of the research into cultural immersion field experience for teachers. Teaching and Teacher Education, 62, 47-59. doi: 10.1016/j.tate.2016.11.002

[25] Sokolova, E.I. (2017). Strany - lidery nepreryvnogo obrazovanija v Evrope [Countries - leaders of continuing education in Europe]. Nepreryvnoe obrazovanie: XXI vek [Continuing Education: XXI Century], 2(18). Retrieved from:

https://cyberleninka.ru/article/v/strany-evropeyskie-lideryv-oblasti-nepreryvnogo-obrazovaniya (in Russian)

[26] Steeg, S., Maier, T. (2019). Dual higher education study or advanced training - What increases the chances of career advancement? Federal Institute For Vocational Education and Training. Retrieved fromhttps://www.bibb.de/en/96309.php

[27] Verbitsky, A.A. (2010). Kontekstno-kompetentnostnyj podhod $\mathrm{k}$ modernizacii obrazovanija // Vysshee obrazovanie v Rossii [Context-competency-based approach to the modernization of education], Higher Education in Russia, 5, 32-37.

[28] Vlasov, S.A. (2013). Axiology of modern Russian education system. Context and Reflection: Philosophy of the World and Human Being, (3-4), 52-57. Retrieved from http://publishing-vak.ru/file/archive-philosophy-2013-3/3vlasov.pdf (in Russian) 